\title{
Advances in belief dynamics: Introduction
}

\author{
F. Liu · O. Roy
}

Received: 11 December 2009 / Accepted: 11 December 2009 / Published online: 3 January 2010

C) The Author(s) 2010. This article is published with open access at Springerlink.com

Contemporary models of beliefs and information have taken the interactive and the dynamic path. They have outgrown the traditional epistemological paradigm of a single agent facing a static environment by first looking at multi-agent scenarios and their crucial "higher-order" component-i.e. belief about beliefs or information about information - and, second, by drawing attention to changes incurred to these attitudes in dynamic situations. Synthese: Knowledge, Rationality \& Action has proved an important platform for the diffusion of contemporary research along these two lines, witness, e.g. Ågotnes et al. (2009) and van Ditmarsch et al. (2009), a trend that we proudly follow in the present special issue.

The themes of interaction and information dynamics have, of course, not been pursued in parallel. As is often the case in logic (Gabbay et al. 2003), their product generated a rich, but rather complex array of new problems. Table 1 gives a bird's eye view of the resulting landscape, which will help us situate the contributions in the present issue.

The top-left cell (a) is the classical locus of investigation in epistemology: the individual knower and her static environment (Steup 2001). It is also the origin of most logical investigations into the concepts of knowledge and beliefs, i.e. with the pioneering work of (Hintikka 1962). Many fundamental issues are still being studied in this area, e.g. the notion of awareness (e.g., Fagin et al. 1988; Ågotnes and Alechina 2007), or the "logical omniscience" problem (Vardi 1986; Duc 1995). Epistemic logic, however, has grown multi-dimensionally.

\footnotetext{
F. Liu (ه)

Department of Philosophy, Tsinghua University, Beijing, China e-mail: fenrong@tsinghua.edu.cn

O. Roy

Faculty of Philosophy, University of Groningen, Groningen, The Netherlands e-mail: o.roy@rug.nl
} 
Table 1 Two axes for the analysis of beliefs

\begin{tabular}{|l|l|l|l|}
\hline & Individual & Multi-agent & $\begin{array}{l}\text { Group or collec- } \\
\text { tives }\end{array}$ \\
\hline Static & $(\mathrm{a})$ & (b) & $\begin{array}{l}\text { (c) Daniele } \\
\text { Porello's contri- } \\
\text { bution }\end{array}$ \\
\hline $\begin{array}{l}\text { Conditioning } \\
\text { and } \\
\text { Kinematics }\end{array}$ & $\begin{array}{l}\text { (d) John } \\
\text { Cantwell's } \\
\text { contribution }\end{array}$ & $(\mathrm{e})$ & $(\mathrm{f})$ \\
\hline Dynamics & $\begin{array}{l}\text { (g) Sven Ove } \\
\text { Hansson's } \\
\text { contribution }\end{array}$ & $\begin{array}{l}\text { (h) Natasha } \\
\text { Alechina and } \\
\text { Brian Logan's } \\
\text { contribution }\end{array}$ & $(\mathrm{i})$ \\
\hline
\end{tabular}

On moving to the right in the table one gradually departs from the individual paradigm towards an understanding of beliefs and information in social contexts. The first step in this direction is to acknowledge that in such contexts, individual beliefs and information bear not only on the state of a given environment, but also on what others believe and know about this environment, about what they believe and know about what the others believe and know, and so on. Multi-agent epistemic logic, see e.g. (Fagin et al. 1995) and (Meyer and van der Hoek 1995), has proved very useful in shedding light on this distinguishing feature of beliefs in interaction.

One can go further, acknowledging the social or interactive aspects of beliefs and information, cell (c), and try to understand how such attitudes can be meaningfully attributed, not to individuals but to groups or collective agents. One way of doing so is by investigating the conditions under which a group attitude can be derived from those of the group's members. Preference aggregation, belief merging, and judgement aggregation are studies of that kind, in which Daniele Porello's contribution to this issue also falls. He explores the logical relationship between preference aggregation and judgement aggregation, an issue that has been much discussed in recent years. To compare Arrow's theorem (Arrow 1963) with the impossibility result for judgement aggregation, List and Pettit $(2002,2004)$ used the notion of ranking judgments. This allowed them to embed the framework of preference into the framework of judgements. Daniele Porello studies the opposite direction, showing that the impossibility of aggregation of ranking judgments can be derived from an Arrovian preference aggregation framework.

John Cantwell's contribution brings us back to the single agent case, but moves one step along the vertical axis of Table 1, cell (d), where updates in the agent's beliefs and information come into the picture. This is the traditional area of decision theory, e.g (Savage 1954; Jeffrey 1965), and recently of conditional doxastic logic (Baltag and Smets 2006), both of which try to understand how an agent's probabilistic or graded beliefs should be updated in the face of new information. John Cantwell's contribution takes a stance in the debate between evidential (Jeffrey 1965) and causal (Joyce 1999) decision theorists, debunking a purported counterexample (Egan 2007) to the latter. In 
the course of doing so, he advocates a fundamental change in the way we understand decision theory, arguing that we should see it as a theory of rational decision making rather than a theory of rational acts, and as one that recommends different policies of belief change, "Bayesian conditioning" vs "imaging," in different circumstances.

Sven Ove Hansson's contribution also keeps to the single agent case, but from the point of view of belief revision theory (Alchourron et al. 1985; Rott 2001), i.e. cell (g). Here one considers how to update one's beliefs in the face of new information that typically contradicts one's previous beliefs. In this issue, against the backdrop of a vast literature on iterated revision, Sven Ove Hansson looks in particular at a realistic phenomenon of multiple belief contraction, i.e. simultaneously retracting a number of previously held beliefs. He provides an axiomatization for both iterated and finite multiple contraction, that is, contraction by a finite set of sentences. In addition, he shows how the finite multiple contraction can be reduced to a single-sentence contraction, and how iterated contraction can be reduced to an order-sensitive, single-step, single-sentence contraction.

Natasha Alechina and Brian Logan brings this general view to the multi-agent case, cell (h), for agents whose memory, time and computational resources are bounded. They take an approach developed by (Ågotnes et al. 2007) to model the process of deriving consequences from a new item of information together with agents' previous beliefs, and apply it to cope with the problem of belief ascription, i.e. assigning beliefs to another agent. They show that, in the general case, correct belief ascription cannot be guarantied for resource-bounded agents, even in the limit, but that one can circumvent this problem by assigning "reasoning strategies", or preference on formulas, to the agents.

Last but not least, it is worth drawing attention on the three cells of Table 1, which represent three areas of research that are not covered in this issue: (e), (f) and (i). The first two are actually a very actives areas: the interactive epistemology, expanding the resources of Bayesian decision theory to cope with the multi-agent case (Aumann 1999; Brandenburger 2007), and the Bayesian aggregation literature (Risse 2003). The last one, by contrast, has received much less investigation. What should the dynamics of group attitudes look like? Are the contemporary tools for analyzing individual and interactive information dynamics sufficient, maybe in combination with resources from the theory of judgment and Bayesian aggregation, to explore this terra incognita? These are questions that can only be answered by further investigation. It is our hope, however, that the contributions in this issue will pave the way.

Acknowledgements The editors would like to thank the participants to the workshop "GLLC XV: The Dynamics of Preferences and Intentions," from which stem most contributions to this special issue. Financial support from the Nederlandse Organisatie voor Wetenschappelijk Onderzoek (NWO), grant \#2008/00804/EW, is gratefully acknowledged.

Open Access This article is distributed under the terms of the Creative Commons Attribution Noncommercial License which permits any noncommercial use, distribution, and reproduction in any medium, provided the original author(s) and source are credited. 


\section{References}

Ågotnes, T., \& Alechina, N. (2007). Full and relative awareness: A decidable logic for reasoning about knowledge of unawareness. In TARK '07: Proceedings of the 11th conference on theoretical aspects of rationality and knowledge, New York, NY, USA (pp. 6-14). ACM.

Ågotnes, T., Alechina, N., \& Logan, B. (Eds.). (2007). Proceedings of the workshop on logics for resource-bounded agents (LRBA 2007). Multi-agent logics, languages and organisations federated workshops, Durham, UK.

Ågotnes, T., van Benthem, J., \& Pacuit, E. (2009). Logic and intelligent interaction. Synthese, 169(2).

Alchourron, C. E., Gardenfors, P., \& Makinson, D. (1985). On the logic of theory change: Partial meet contraction and revision functions. Journal of Symbolic Logic, 50(2), 510-530.

Arrow, K. (1963). Social choice and individual values. New York: Wiley.

Aumann, R. (1999). Interactive epistemology I: Knowledge. International Journal of Game Theory, $28,263-300$

Baltag, A., \& Smets, S. (2006). Conditional doxastic models: A qualitative approach to dynamic belief revision. In G. Mints \& R. de Queiroz (Eds.), Proceedings of WOLLIC 2006. Electronic notes in theoretical computer science (Vol. 165).

Brandenburger, A. (2007). The power of paradox: Some recent developments in interactive epistemology. International Journal of Game Theory, 35, 465-492.

Duc, H. N. (1995). Logical omniscience versus logical ignorance-on a dilemma of epistemic logic. In: Proceedings of the 7th Portuguese conference on artificial intelligence: Progress in artificial intelligence (pp. 237-248).

Egan, A. (2007). Some counterexamples to causal decision theory. The Philosophical Review, 116, $93-114$.

Fagin, R., Halpern, J. Y., Daniel, R., \& Bobrow, G. (1988). Belief, awareness, and limited reasoning. Artificial Intelligence, 34, 39-76.

Fagin, R., Halpern, J., Moses, Y., \& Vardi, M. (1995). Reasoning about knowledge. Cambridge, MA: MIT Press.

Gabbay, D., Kurusz, A., Wolter, F., \& Zakharyaschev, M. (2003). Many-dimensional modal logics: Theory and applications. Amsterdam: Elsevier.

Hintikka, J. (1962). Knowledge and belief: An introduction to the logic of two notions. Ithaca, NY: Cornell University Press.

Jeffrey, R. (1965). The logic of decision. New York: McGraw-Hill.

Joyce, J. (1999). The foundations of causal decision theory. Cambridge: Cambridge University Press.

List, C., \& Pettit, P. (2002). Aggregating sets of judgments: An impossibility result. Economics and Philosophy, 18, 89-110.

List, C., \& Pettit, P. (2004). Aggregating sets of judgments: Two impossibility results compared. Synthese, 140(1-2), 207-235.

Meyer, J.-J., \& van der Hoek, W. (1995). Epistemic logic for computer science and artificial intelligence, No. 41 in Cambridge tracts in theoretical computer science. Cambridge: Cambridge University Press.

Risse, M. (2003). Bayesian group agents and two modes of aggregation. Synthese, 135(3), 347-377.

Rott, H. (2001). Change, choice and inference: A study of belief revision and nonmonotonic reasoning. Oxford logic guides. Oxford: Oxford University Press.

Savage, L. (1954). The foundations of statistics. New York: Dover Publications Inc..

Steup, M. (2001). The analysis of knowledge. In E. Zalta (Ed.), The Stanford encyclopedia of philosophy. Stanford: The Metaphysics Research Lab, CSLI.

van Ditmarsch, H., Hill, B., \& Majer, O. (2009). Logic of change, change of logic. Synthese, 171(2), 227-234.

Vardi, M. Y. (1986). On epistemic logic and logical omniscience. In TARK '86: Proceedings of the 1986 conference on theoretical aspects of reasoning about knowledge, San Francisco, CA, USA. (pp. 293-305). San Francisco: Morgan Kaufmann Publishers Inc. 